\title{
THE USE OF THE THREE-PHASE BONE SCAN IN THE EARLY DIAGNOSIS OF HETEROTOPIC OSSIFICATION (HO) AND IN THE EVALUATION OF DIDRONEL THERAPY
}

\author{
By J. H. Freed, M.D., H. Hahn, M.D., R. Menter, M.D. and T. Dillon, M.D. \\ Craig Hospital, Rocky Mountain Regional SCIS and \\ Swedish Medical Center, Englewood, Colorado
}

\begin{abstract}
The purpose of this study is to investigate the use of a three-phase bone scan for early detection of $\mathrm{HO}$ formation and as a method of evaluating Didronel treatment.

A marked vascular blush and blood pool was noted about the hips sometimes with a normal bone scan and normal X-ray of the hips. This appeared to represent the precursor phase of $\mathrm{HO}$ formation since, on repeat scans, the bone scan showed accumulation of the bone-seeking radionuclide usually in 2 to 4 weeks and the X-ray revealed ossification.

Fifty-two patients treated with Didronel between October 1978 and December 1979 were reviewed to determine the value of Didronel treatment.

There were 23 patients in the series who either showed $\mathrm{HO}$ by X-ray on admission or developed HO on follow-up X-rays before beginning Didronel therapy. A threephase bone scan revealed increased vascularity and accumulation of radioactivity on the bone scan in all areas of ossification on the X-ray and in some areas that did not appear to be involved. The other 29 patients had serial three-phase bone scans, X-ray study, and an alkaline phosphatase determination at approximately 2-week intervals.

Didronel treatment was started as soon as the precursor phase of $\mathrm{HO}$ was demonstrated on the three-phase bone scan in most of these patients. Nine have not developed ossification that could be seen in X-rays during 3 months of continuing study.

Six patients seen at follow-up during the past year had known HO of 4 to 7 years' duration. The three-phase bone scan was used to predict the maturity of $\mathrm{HO}$ in these patients.

Our study indicates that increased vascularity precedes rather than being secondary to $\mathrm{HO}$ formation as is suggested in the literature. Didronel treatment appears to be most effective if initiated during this precursor phase.
\end{abstract}

Key words: Spinal cord injury; heterotopicossification;Three-phase bone scan; Didronel.

\section{Introduction}

HETEROTOPIC ossification is a frequent complication of spinal injury and is occasionally seen following brain injury. The reported incidence varies from to to 25 per cent (Hsu et al., I975; Wharton, I975), with the hip joint being the most common joint affected. In spite of many investigations, the aetiology and pathogenesis of heterotopic ossification is still unknown. Extensive studies have been undertaken to determine if any of the known diagnostic criteria is of value in predicting the maturity of heterotopic ossification in order to decide whether surgical intervention might be utilised in the correction of the disabling articular joint freedom without a high incidence of recurrence.

Rossier et al. (1973) in an extensive review of the problem attempted to answer the question of aetiology and maturity by evaluating the general methods of study and by adding angiography and a bone scan. In a study of 36 angiographies in I 7 patients they found that serial angiograms demonstrated arteriovenous shunting, 
but that such serial studies were complicated by haematoma formation and subsequent scar tissue formation. They concluded that the angiographic modifications (increased vascularity and early venous return) associated with $\mathrm{HO}$ were secondary to the $\mathrm{HO}$ and not a cause.

Bone scanning at that time was in its infancy and the only readily available bone scanning agents were ${ }^{85} \mathrm{Sr}$ and ${ }^{87 \mathrm{~m}} \mathrm{Sr}$, both of which had limitations for producing good serial bone scans. Their studies, however, did indicate that serial bone scans appeared to be the most reliable parameter for deciding when $\mathrm{HO}$ is mature and an operation may be indicated.

The development and use of Technitium-99m tagged polyphosphates by Subramanian and McAfee (I97I) as bone-seeking radionuclides marked a major rapid advance in the diagnostic value of bone scanning since its short half-life of 6 hours makes it possible to give it in sufficient quantity to perform a three-phase bone scan.

The purpose of our study was to investigate the use of a three-phase bone scan for early detection of $\mathrm{HO}$ formation and to utilise it as a method of evaluating Didronel treatment.

\section{The Three-Phase Bone Scan}

The technique of study is as follows: with the patient lying supine, the pelvis and hips are centred under a Picker 4/I 5 anger camera with ultra-fine low energy collimator and 20 per cent window. A toruniquet is placed on the arm, 20 millicuries of Technetium-99m Methylene Diphosphonate is injected into an antecubital vein, and the tourniquet is then released. The imaging procedure commences as soon as radioactivity is noted in the iliac arteries. The three phases are:

Phase I Dynamic blood flow study consisting of six photoscans at Io-second intervals over the hips.

Phase II An immediate static scan to demonstrate the blood pool about the hips.

Phase III A 2-hour bone scan to visualise the degree of accumulation of the bone-seeking radionuclide about the hips, hereafter referred to as a positive bone scan.

A moderate increased vascularity was noted on the dynamic flow study and blood pool (Phase I and II) about the hips on 26 October I979 and shown in Fig. I. This increased vascularity can occur without any evidence of accumulation of the bone-seeking radionuclide about the hips on the bone scan (Phase III) of 26 October I979 (Fig. 2).

A repeat three-phase bone scan on I 5 November I979, 3 weeks later, revealed a marked increased vascularity on the blood flow study and a markedly positive bone scan (Fig. 3) with a continuing normal X-ray of the pelvis.

Since increased vascularity preceded a positive bone scan from 2 to 4 weeks, this period of increased vascularity, detected in Phase I and II of the three-phase bone scan, was considered the precursor phase of $\mathrm{HO}$.

A positive bone scan (Phase III) was found to precede ossification by 4 weeks or more in the untreated patient.

The following patient, a quadraplegic, developed swelling of the left hip and elevated alkaline phosphatase. A three-phase bone scan was performed on I5 January I979 which revealed increased blood flow and a positive bone scan (Phase III) as shown in Fig. 4. The X-ray of the pelvis was normal. 


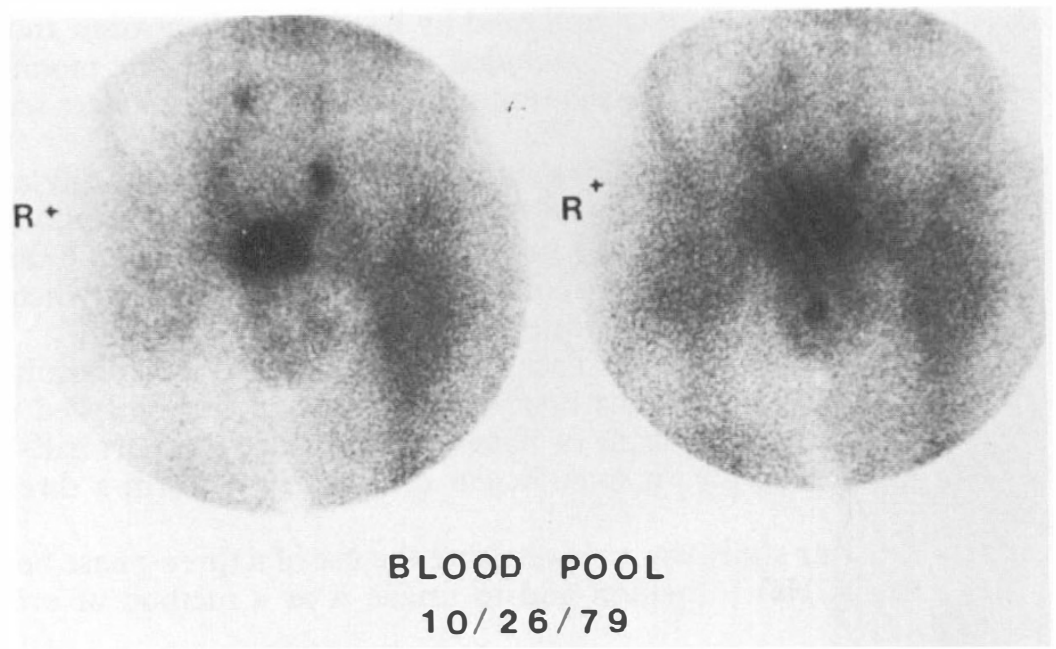

FIG. I

Moderate increased vascularity on dynamic flow study and blood pool.

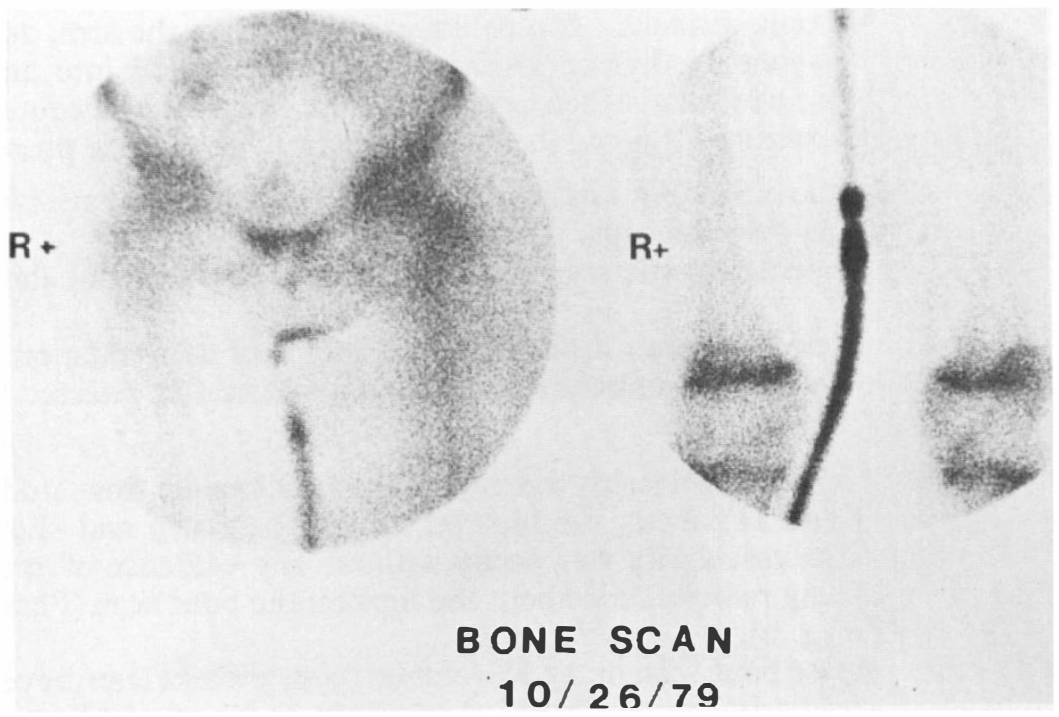

FIG. 2

Normal bone scan.

The three-phase bone scan repeated at I month intervals showed an increase in the blood flow and bone scan activity with a continuing normal X-ray of the pelvis until the third study on I5 March I 979 when slight ossification was noted about the left lesser trochanter, 2 months after a positive bone scan.

Thus, we found that the three-phase bone scan detects early $\mathrm{HO}$ formation often 4 to 6 weeks before ossification is evidenced about the hips on the X-ray study in the untreated patient. 

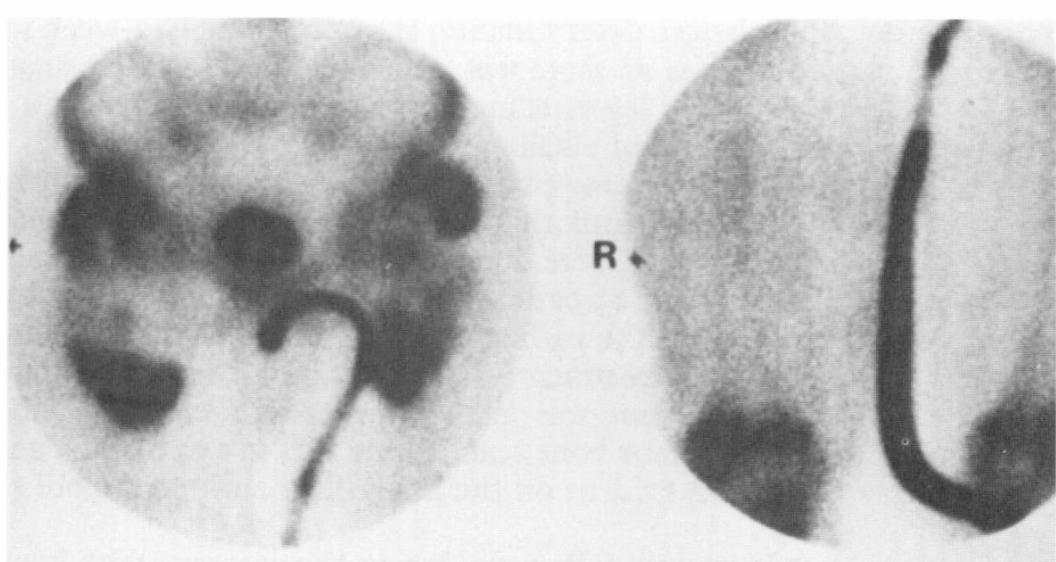

\section{BONE SCAN}

\section{FIG. 3}

Marked increased vascularity on the blood flow study with a markedly positive bone scan.

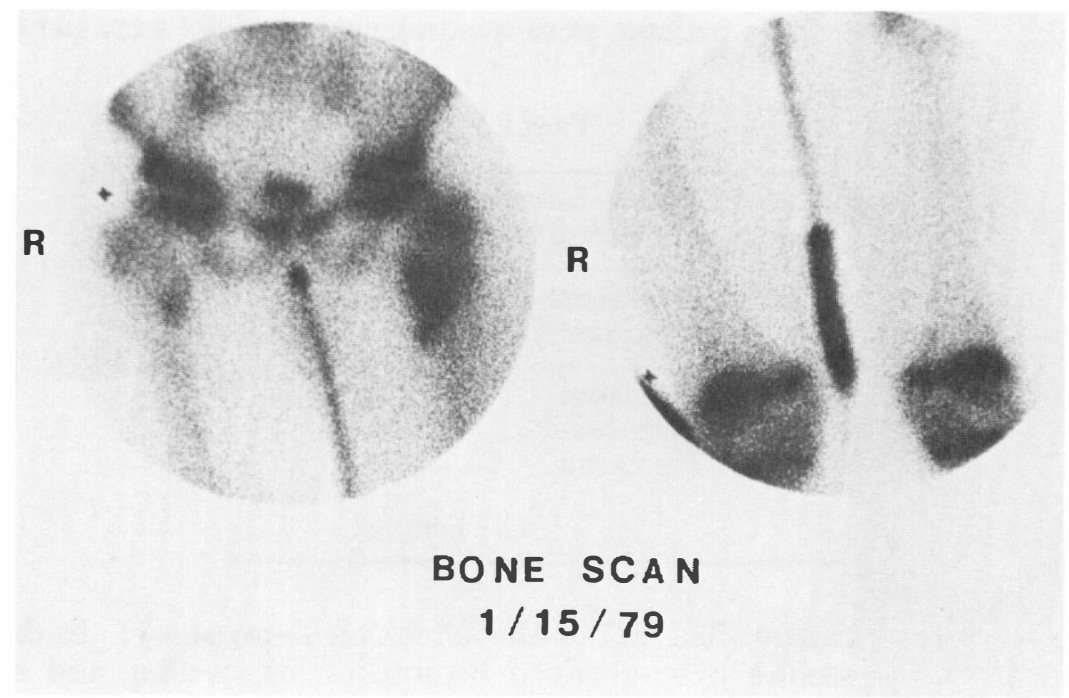

FIG. 4

Increased blood flow and a positive bone scan.

\section{Didronel Treatment}

Fifty-two patients with early spinal cord injuries were treated with Didronel between October 1978 and December 1979 and were studied to determine the value of the three-phase bone scan in the diagnosis of $\mathrm{HO}$ formation and Didronel in the treatment. A protocol was established which included at least an X-ray of the pelvis, hips and knees on admission and discharge, one three-phase bone scan 
and a serial alkaline phosphatase determination at approximately 2-week intervals. The study was initiated as soon as there was any clinical evidence to suggest $\mathrm{HO}$ formation as indicated by either leg swelling, loss of range of motion of a joint or progressive elevation of the level of alkaline phosphatase.

In the first 23 patients, a three-phase bone scan was not performed and Didronel therapy was deferred until there was evidence of ossification on the $\mathrm{X}$-ray study. Serial X-ray studies were done to evaluate Didronel treatment.

Based on the finding in these 23 patients, the protocol was changed to include serial three-phase bone scans in the earlier diagnosis of $\mathrm{HO}$ and as an additional method of evaluating Didronel treatment. Twenty-nine patients are included in this study and Didronel treatment was given as soon as there was evidence of increased vascularity on the 2-hour bone scan (Phase III) in I 7 patients, and when only increased vascularity was evident on the blood flow and blood pool (Phase I and II) in 12 patients.

Six patients seen at long-term follow-up during the past year with known $\mathrm{HO}$ of 4 to 7 years duration were evaluated by a three-phase bone scan to determine its value in predicting the maturing of $\mathrm{HO}$.

\section{Findings}

Didronel appeared to have a variable effect depending on when the treatment was started. The findings in the first series of 23 patients in which Didronel was withheld until there was evidence of ossification on the X-ray study is shown in Table I. Seventeen of the patients were quadraplegics and six were paraplegics.

\section{TABLE I}

\begin{tabular}{cc}
$\begin{array}{c}\text { Effects of Didronel treatment when ossification } \\
\text { was present before beginning treatment }\end{array}$ \\
\hline $\begin{array}{cc}\text { Changes on serial X-ray } \\
\text { studies }\end{array}$ & X-ray \\
\hline $\begin{array}{c}\text { Increased } \\
\text { Decreased } \\
\text { No change }\end{array}$ & $9(40 \%)$ \\
& 8 \\
\hline & Total 23 \\
\hline
\end{tabular}

Seven of these patients had HO on the admission X-ray study. In the other I 6 patients, X-ray studies were obtained because of leg swelling and elevated alkaline phosphatase. A three-phase bone scan revealed increased vascularity and accumulation of radioactivity on the bone scan in all areas of ossification on the $\mathrm{X}$-ray and in some areas that did not appear to be involved on the initial X-ray study. Only six of these patients had repeat three-phase bone scans. This study seemed to indicate that Didronel was inhibiting further ossification already present. All of these patients had mild to marked elevation of the alkaline phosphatase before ossification was evident on the X-ray. Didronel therapy was usually continued for only 3 months in these patients.

The findings in the 29 patients in which Didronel treatment was started in the precursor phase (Phase I and II) or bone scan (Phase III) are shown in Table II. 
A serial three-phase bone scan, X-ray study and an alkaline phosphatase determination were performed on these 29 patients at approximately 2 -week intervals. Eighteen of the patients were quadraplegics and I I were paraplegics.

\section{TABLE II}

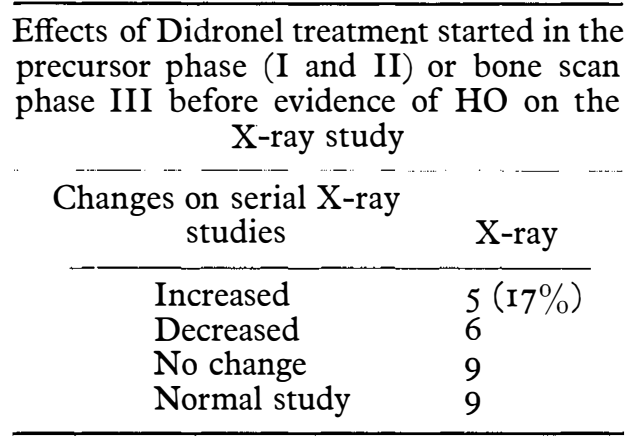

Nine patients had no ossification on serial X-ray studies followed 2 to 3 months before discharge. Five of these patients had a normal alkaline phosphatase determination during the precursor phase of HO (Phase I and II), but developed mild to moderate elevation of alkaline phosphatase on serial studies. Thus, serial alkaline phosphatase determinations were elevated in all 29 patients. All will continue on Didronel for 3 to 6 months.

Didronel treatment was started as soon as the blood flow and bone scan showed increased radioactivity in 17 patients with a normal X-ray. Although all developed varying degrees of stippled or linear areas of ossification in 2 to 4 weeks in areas of increased activity on the bone scan, the ossification remained less organised and showed less evidence of progression on serial X-ray studies with this earlier treatment over a period of 2 to 3 months before discharge.

The results were sufficiently encouraging to warrant starting Didronel treatment as soon as the blood flow and blood pool showed increased vascularity with both a normal bone scan and normal X-ray.

The three-phase bone scan was further utilised to determine its use in predicting the maturity of HO. Six patients seen at follow-up during the past year had known HO for 4 to 7 years' duration. A three-phase bone scan showed an absence of vascularity about the hips and the activity on the bone scan was equal to that of the adjacent normal bone of the iliac border of the pelvis in five patients indicating that their $\mathrm{HO}$ was mature. Three had no significant limitation of motion requiring surgery. One patient with bilateral frozen hips is awaiting surgery. The other patient with known $\mathrm{HO}$ for 5 years and a frozen left hip had a normal bone scan and his $\mathrm{X}$-ray suggested that his $\mathrm{HO}$ bone was mature. The surgeon reported his $\mathrm{HO}$ bone was easily resected with only a $50 \mathrm{cc}$ blood loss and no postoperative complications.

The three-phase bone scan in the sixth patient with known $\mathrm{HO}$ for 5 years and a frozen right hip revealed increased vascularity and marked activity on the bone scan indicating that his $\mathrm{HO}$ was still immature. Those interpreting the $\mathrm{X}$-ray study reported the $\mathrm{HO}$ bone as appearing mature. He elected to have surgery and was placed on Didronel for 4 weeks prior to resection of a portion of the mass to restore hip mobility. There was rather marked bleeding (5000 $\mathrm{cc}$ blood loss) at 
surgery making resection difficult with many postoperative complications. A repeat three-phase bone scan I month later and just prior to discharge revealed increased vascularity and intense activity in the bone scan, characteristic of the precursor phase of $\mathrm{HO}$ at the operative site without recurrent ossification on the X-ray. Didronel treatment is being continued for an additional 3 months and, if further follow-up does not show recurrent ossification, it will further enhance the value of Didronel therapy.

Our study of these 6 patients with $\mathrm{HO}$ of 4 to 7 years' duration confirms the conclusion made by Rossier et al. (1973) that the bone scan is the most reliable parameter for determining when $\mathrm{HO}$ is mature and may be ready for operation. The absence of vascularity in the three-phase bone scan adds another dimension to this conclusion.

\section{Discussion}

Didronel appears to be delaying and even inhibiting calcium hydroxyapatite crystal formation and limiting the degree of ossification already present in this series of 52 patients. These findings are in accordance with the reported action of Didronel in inhibiting crystal resorption and crystal growth, as reported by others (Francis et al., I969; Russell \& Smith, I973; Rosenthall \& Kay, I976).

The suggested effect of Didronel on the 3 patients with only increased vascularity is unexplained and it is possible this vascularity would have reresolved without treatment. The $\mathrm{HO}$ protocol has now been modified further to include a three-phase bone scan and X-ray study at the time of admission on all patients admitted to Craig Hospital with or without clinical findings or elevation of the alkaline phosphatase. Patients with moderate to marked increased vascularity, believed to be a risk for extensive ossification, or with clinical findings and unexplained progressive elevation of alkaline phosphatase will be placed on Didronel therapy.

Our studies indicate that 3 months of Didronel treatment is inadequate and that it should be continued for 6 months or until serial bone scans performed at approximately 3 -month intervals return to normal. This will be further evaluated in our future studies.

Another interesting observation has been made on 5 paralytic patients with unsuspected $\mathrm{HO}$ formation and a fever of unknown origin referred for Gallium-67 scans to confirm or exclude inflammation or abscess formation. Three millicuries of Gallium-67 was injected intravenously and total body scans made at 6 and 24 hours. There was marked accumulation of Gallium-67 about one or both hips with no other findings to account for the elevated temperature in these patients. Therefore, it was concluded that this marked Gallium uptake must be due to HO formation. This was confirmed by a follow-up three-phase bone scan 5 days later. Ossification was noted either on the initial or serial X-ray study in all 5 patients. Since Gallium-67 is known to accumulate in areas of inflammation, the Gallium-67 uptake in these 5 patients appears to be due either to inflammatory changes in acute $\mathrm{HO}$ or related in some other way to the increased vascularity present in the precursor phase of $\mathrm{HO}$ formation.

\section{SUMMARY}

Heterotopic ossification is a frequent complication of spinal injury and is occasionally seen following brain injury. Fifty-two patients with early spinal cord 
injuries were treated with Didronel between October 1978 and December 1979 and were studied to determine the value of the three-phase bone scan in the diagnosis of $\mathrm{HO}$ formation and Didronel in their treatment.

\section{The results of this study indicate:}

I. Increased vascularity which we have termed the precursor phase of HO precedes rather than being secondary to $\mathrm{HO}$ formation as suggested by Rossier et al. (1973).

2. The three-phase bone scan detects HO formation generally 4 to 6 weeks before ossification is evident on the X-ray study in the untreated patient.

3. The alkaline phosphatase is elevated in patients with acute $\mathrm{HO}$ before ossification is evident on the X-ray.

4. Didronel appears to be of value in the treatment of $\mathrm{HO}$ and is most effective if started in the precursor phase (Phase I \& II) or bone scan (Phase III) before ossification is evident on the X-ray.

5. The serial three-phase bone scan is a reliable method of determining the maturity of $\mathrm{HO}$.

\section{RÉSUMÉ}

L'ossification hétérotopic est une complication fréquente des lésions spinales et, par occasion, elle est observée aprês une lésion cérébrale. Cinquante-deux malades atteints des lésions primaires du cordon médullaire étaient traités avec Didronel entre les mois d'octobre I978 et décembre 1979; des études etaient faites pour évaluer l'utilité d'éxamen triphasé (three-phase bone scan) dans le diagnostic de l'ossification hétérotopic et d'emploi de Didronel.

\section{L'étude montre:}

I. La vascularité élevée, que nous avon désignée comme phase précurseur de l'ossification hétérotopic, précède l'ossification et n'est pas une conséquence de l'ossification, comme ont proposé Rossier et al. (1973).

2. L'éxamen triphasé (three-phase bone scan) en général, décèle l'ossification hétérotopic entre quatre et six semaines avant l'ossification est noté par l'éxamen à rayons $\mathrm{X}$ dans le malade non-traité.

3. La phosphatase alkaline est élevée dans les malades atteints par l'ossification aigu avant que l'ossification se manifeste par l'éxamen à rayons $\mathrm{X}$.

4. Il apparait que le traitement avec Didronel est utile et plus efficace si on commence pendant la phase précurseur (Phase I et II) ou avant que l'ossification peut être décélé par l'éxamine à rayons $\mathrm{X}$ (Phase III).

5. L'éxamen triphasé en série (serial three-phase bone scan) est une méthode éfficace pour déterminer le stade de l'ossification hétérotopic.

\section{ZUSAMMENFASSUNG}

Die heterotope Ossifikation ('heterotopic ossification', im folgenden: HO) ist eine haüfige Komplikation bei Rückgratsverletzungen und kann gelegentlich als Folge von Hirnverletzungen beobachtet werden. Funfzig-zwei Patienten mit frühen Rückenmarksbeschädigungen wurden in der zeit von Oktober 1978 bis Dezember 1979 mit Didronel behandelt. Sie wurden untersucht, um den Wert sowohl der 3-Phasen-Knochenbetrachtungs-Methode ('Three-phase bone scan') für die Diagnose der HO-Formierung als auch des Didronel in der Behandlung zu ermitteln.

Die Ergebnisse dieser Untersuchung zeigen:

I. Zunehmende Vaskularität, die wir als präkursive Phase ('precursor phase') von HO bezeichnet haben, geht der $\mathrm{HO}$ voraus und gilt nicht als sekundär für $\mathrm{HO}$ Formierung, wie dies Rossier et al., I973 annehmen. 
2. Die 3-Phasen-Knochenbetrachtungs-Methode zeigt die HO-Formierung im allgemeinen 4-6 Wochen bevor die Ossifikation in der Röntgenuntersuchung des unbehandelten Patienten sichtbar wird.

3. Die 'alkaline phosphatase' wird bei Patienten mit akuter $\mathrm{HO}$ angehoben, bevor die Ossifikation auf dem Röntgenschirm sichtbar wird.

4. Didronel scheint in der Behandlung von $\mathrm{HO}$ von Nutzen su sein und erreicht seine beste Wirkung, wenn man mit der Behandlung in der 'precursor'-Phase (Phase I und II) oder 'bone scan'-Phase (Phase III) bevor die Ossifikation auf dem Bildschirm sichtbar wird, beginnt.

5. Die serienmässige 3-Phasen-Knochenbetrachtungsmethode stellt eine verlässliche Methode dar, un den Entwicklungsgrad der $\mathrm{HO}$ zu ermitteln.

\section{REFERENCES}

Francis, M. D., Russell, R. G. G. \& Fleisch, H. (1969). Diphosphonates inhibit formation of calcium phosphates in vitro and pathological calcification in vivo: Science, I65, I264.

Hsu, J. D., SAKimura, Ivan \& StaufFer, E. S. (I975). Heterotopic ossification around the hip joint in spinal cord injured patients. Clin. Orthop., I12, I65-169.

Rosenthall, L. \& KaYe, M. (1976). Observations on the mechanism of 99mTc-labelled phosphate complex uptake in metabolic bone disease. Sem. Nucl., Med., 59-67.

Rossier, A. B., Bussat, P. H., Infante, F., Zender, R., Courvoisier, B., Muheim, G., Donath, A., Vasey, H., Taillard, W., Laiger, R., Gabbani, G., Baud, C., Pouezat, J. A., Very, J. M. \& HACHeN, H. J. (I973). Current facts on para-osteo-arthropathy (POA). Paraplegia, II, 36-78.

Russell, R. G. G. \& Smith, R. (1973). Diphosphonates. F. Bone Foint Surg. (Br), 55-66.

Subramanian, G. \& McAfeE, J. G. (I97I). A new complex of ${ }^{99 \mathrm{~m}}$ Tc for skeletal imaging. Radiology, 99, 192.

Wharton, G. W. (I975). Heterotopic ossification. Clin. Orthop., II2, I42-I49. 